\title{
ВПЛИВ ТИРЕОЇДНИХ ГОРМОНІВ НА ПРОЦЕСИ РЕМЕТИЛУВАННЯ ТА ТРАНССУЛЬФУВАННЯ СІРКОВМІСНИХ АМІНОКИСЛОТ В ОРГАНАХ ЩУРІВ
}

Вступ. Сірковмісні амінокислоти забезпечують процеси життєдіяльності клітини і процеси метилування, підтримують редокс-потенціал та цілісність клітинних систем, знешкоджують токсичні агенти і вільні радикали. Порушення їх обміну асоціюються з рядом патологій, включаючи хворобу Альцгеймера, розвитком злоякісних пухлин, десректами невральної трубки, хворобами нирок. Підвищення в крові концентрації сірковмісної амінокислоти гомоцистеїну (ГЦ) є серйозним фрактором розвитку захворювань серцево-судинної системи, як-от атеросклерозу, гіпертонії, венозного тромбозу. Регуляція метаболізму сірковмісних амінокислот здійснюється на різних рівнях, у тому числі й тиреоїдними гормонами. Встановлено, що гіпотиреоз є незалежним фрактором, який призводить до збільшення концентрації ГЦ у крові та ризику розвитку серцево-судинних захворювань. Проте конкретні молекулярні механізми впливу тиреоїдних гормонів на обмін сірковмісних амінокислот залишаються невідомими.

Мета дослідження - вивчити в експерименті вплив тиреоїдних гормонів на прочеси реметилування та транссульфрування в печінці й нирках, вміст ГЦ, цистеїну і гідроген сульфріду в сироватці крові експериментальних тварин.

Meтоди дослідження. Щурам вводили L-тироксин і мерказоліл для моделювання станів гіпер- та гіпотиреозу, які підтверджували за вмістом вільного тироксину, вільного трийодтироніну і тиреотропного гормону в сироватці крові.

Результати й обговорення. У печінці й нирках тварин з гіпотиреозом спостерігали зниження активності фрерментів циклу реметилування - S-аденозилметіонінсинтетази, S-аденозилгомоцистеїнгідролази, бетаїнгомоцистеїнметилтрансферази та фрерментів транссульфрування - цистатіонін- $\beta$ синтази, цистатіонін-у-ліази і цистеїнамінотрансферази. При моделюванні гіпертиреозу активність даних фрерментів у досліджуваних органах підвищувалася. Гіпертиреоз супроводжувався зниженням концентрації ГЦ, а гіпотиреоз - зростанням концентрації ГЦ, цистеїну та зменшенням вмісту гідроген сульфріду в крові тварин.

Висновок. Вагомими фракторами ризику розвитку атеросклерозу, ендотеліальної дисфрункції та гіперкоагуляції при гіпотиреоїдних станах можуть бути порушення процесів реметилування і транссульфрування сірковмісних амінокислот в органах.

КЛЮЧОВІ СЛОВА: тиреоїдні гормони; сірковмісні амінокислоти; цикл реметилування; шлях транссульфування; гомоцистеїн; цистеїн; гідроген сульфрід.

ВСТУП. Сірковмісні амінокислоти забезпечують процеси життєдіяльності клітини і процеси метилування, підтримують редокс-потенціал та цілісність клітинних систем, знешкоджують токсичні агенти і вільні радикали. Особливу увагу приділяють обміну гомоцистеїну (ГЦ) і цистеїну. Підвищення в крові концентрації ГЦє серйозним фрактором ризику розвитку ряду захворювань, зокрема атеросклерозу, венозного тромбозу, гіпертонії [3]. 3 десульфуразним шляхом обміну цистеїну асоціюється продукція важливої регуляторної газової молекули гідроген (c) В. М. Нечипорук, Н. В. Заічко, М. М. Корда, 2017. сульсріду $\left(\mathrm{H}_{2} \mathrm{~S}\right)$. На сьогодні встановлено, що $\mathrm{H}_{2} \mathrm{~S}$ відіграє важливу роль в агрегації тромбоцитів та регуляції судинного тонусу, скоротливості міокарда, нейротрансмісії, секреції інсуліну [4, 9, 13, 14].

Регуляція метаболізму сірковмісних амінокислот здійснюється на різних рівнях, у тому числі й ендокринною системою. Одними 3 ключових гормонів, що регулюють усі види метаболізму в організмі, є тиреоїдні гормони. Було встановлено, що у хворих на гіпотиреоз зростає вміст ГЦ, а замісна терапія тироксином нормалізує даний показник до рівня здорових осіб [10]. K. M. Colleran та ін. [12], досліджуючи пацієнтів 
із короткочасним гіпертиреозом, показали, що короткостроковий субклінічний гіпертиреоз, індукований введенням метімазолу, спричиняє зниження рівня ГЦ у крові. У роботі [5] було показано, що гіпотиреоз $€$ незалежним фрактором, що призводить до збільшення концентрації ГЦ у крові та ризику розвитку серцево-судинних захворювань у хворих з даною патологією. Проте конкретні молекулярні механізми впливу тиреоїдних гормонів на підвищення чи зниження рівня ГЦ залишаються невідомими. Невивченими є процеси обміну цистеїну при гіпер- або гіпотиреозі.

Мета дослідження - вивчити в експерименті вплив тиреоїдних гормонів на процеси реметилування та транссульфування в печінці й нирках, вміст ГЦ, цистеїну і $\mathrm{H}_{2} \mathrm{~S}$ у сироватці крові експериментальних тварин.

МЕТОДИ ДОСЛІДЖЕННЯ. Для дослідження використано 40 безпородних щурів-самців масою 150-180 г, яких утримували на стандартному раціоні. Усіх тварин поділили на 5 груп: 1-ша - інтактні щури, яким вводили інтрагастрально розчин 1 \% крохмалю; 2-га - тварини 3 гіпертиреозом, яким щоденно протягом 14-ти днів вводили інтрагастрально L-тироксин на $1 \%$ розчині крохмалю по 200 мкг/добу на 1 кг маси; 3-тя - тварини 3 гіпертиреозом, яким щоденно протягом 21-го дня вводили інтрагастрально L-тироксин на 1 \% розчині крохмалю по 200 мкг/добу на 1 кг маси; 4-та - тварини з гіпотиреозом, яким щоденно протягом 14-ти днів вводили інтрагастрально мерказоліл на 1 \% розчині крохмалю по 10 мг/добу на 1 кг маси; 5-та - тварини з гіпотиреозом, яким щоденно протягом 21-го дня вводили інтрагастрально мерказоліл на $1 \%$ розчині крохмалю по 10 мг/добу на 1 кг маси. 3 досліду тварин виводили на 15-й і 22-й дні методом цервікальної дислокації. Для експерименту використовували плазму крові, тканину печінки та нирок. Дослідження проведено згідно із загальними етичними принципами експериментів на тваринах.

Печінку та нирки перфузували холодним 1,15 \% розчином калію хлориду і гомогенізували при 3000 об./хв у середовищі 1,15 \% калію хлориду (співвідношення 1:3). Гомогенати центрифругували впродовж 30 хв при $1500 \mathrm{~g}$ та $+4{ }^{\circ} \mathrm{C}$. У печінці та нирках визначали активність S-аденозилметіонінсинтетази (S-AMC) [6], S-аденозилгомоцистеїнгідролази (S-AГГ) [11], бетаїнгомоцистеїнметилтрансфрерази (БГМТ) [8], цистатіонін-ß-синтази (ЦБС), цистатіонін-у-ліази (ЦГЛ) і цистеїнамінотрансорерази (ЦАТ) [1, 7]. Для підтвердження станів гіпер- та гіпотиреозу в сироватці крові визначали вміст вільного тироксину $\left(\mathrm{BT}_{4}\right)$, вільного трийодтироніну (в $\left.\mathrm{T}_{3}\right)$ і тиреотропного гормону (ТТГ) імунофрерментним методом з використанням наборів фрірми "Диагностические системы” (Російська Федерація). У сироватці крові визначали загальний вміст ГЦ імуноферментним методом із застосуванням набору фрірми "Axis-Shield" (Велика Британія). Вміст $\mathrm{H}_{2} \mathrm{~S}$ у сироватці крові визначали за реакцією утворення тіоніну з використанням N,N-диметил-поренілендіаміну [2].

Результати виражали як середнє \pm SEM із 8 експериментів. Зміни $р<0,05$ розглядали як статистично достовірні. Статистичний аналіз виконували, використовуючи стандартні статистичні програми і t-критерій Стьюдента.

РЕЗУЛЬТАТИ Й ОБГОВОРЕННЯ. ЩОДЕНН введення тваринам L-тироксину протягом 14-ти і 21-го днів викликало стан постійного гіпертиреозу (табл. 1), що підтверджувалося збільшенням концентрації в ${ }_{4}$ у крові щурів (на 14-й день - на 83 \%, на 21-й - на 136 \%). Концентрація ТТГ при цьому достовірно зменшувалася (на 14-й день на $56 \%$, на 21-й - на $76 \%$ ). Рівень в з $_{3}$ не змінювався достовірно в обидва терміни дослідження.

Для пригнічення продукції синтезу тиреоїдних гормонів використовували препарат "Мерказоліл", який блокує фрермент пероксидазу, що бере участь у йодуванні тироніну в щитоподібній залозі до трийод- і тетрайодтироніну та знижує інкрецію тироксину. Введення щурам мерказолілу протягом 14-ти днів викликало зниження вмісту в . $_{4}$ сироватці крові на $38 \%$, а подальше введення препарату протягом 21-го дня призвело до зменшення вТ 4 на 62 \%. На відміну від

Таблиця 1 - Вміст вільного тироксину, трийодтироніну (пмоль/л) та тиреотропного гормону (мМО/л) у сироватці крові щурів, яким вводили L-тироксин і мерказоліл $(\mathrm{M} \pm \mathrm{m}, \mathrm{n}=8)$

\begin{tabular}{|c|c|c|c|c|c|}
\hline \multirow{4}{*}{ Показник } & \multicolumn{5}{|c|}{ Група тварин } \\
\hline & \multirow{3}{*}{ інтактні } & \multicolumn{2}{|c|}{ L-тироксин } & \multicolumn{2}{|c|}{ мерказоліл } \\
\hline & & \multicolumn{4}{|c|}{ час від початку введення препаратів, дні } \\
\hline & & 14 & 21 & 14 & 21 \\
\hline ТТГ & $0,34 \pm 0,03$ & $0,15 \pm 0,02^{*}$ & $0,08 \pm 0,01^{*}$ & $0,54 \pm 0,05^{*}$ & $2,21 \pm 0,16^{\star}$ \\
\hline $\mathrm{BT}_{4}$ & $11,07 \pm 0,47$ & $20,23 \pm 2,10^{*}$ & $26,12 \pm 1,85^{\star}$ & $6,84 \pm 0,27^{*}$ & $4,25 \pm 0,42^{\star}$ \\
\hline $\mathrm{BT}_{3}$ & $2,58 \pm 0,24$ & $2,70 \pm 0,18$ & $2,88 \pm 0,21$ & $0,87 \pm 0,06^{*}$ & $0,67 \pm 0,04^{\star}$ \\
\hline
\end{tabular}

Примітка. Тут і в таблицях 2, 3: *- зміни достовірні відносно показників групи інтактних тварин. 
L-тироксину, щоденне введення тваринам мерказолілу протягом 14-ти і 21-го днів спричинило зростання рівня ТТГ на 56 та 550 \%. Концентрація в Т $_{3}$ пр введенні мерказолілу зменшилась у сироватці крові в обидва терміни дослідження, відповідно, на 66 і $74 \%$.

Гомоцистеїн метаболізується одним із двох шляхів - реметилуванням або транссульфруванням. У нормі ГЦ реметилується до метіоніну двома шляхами. Перша реакція каталізується $\mathrm{B}_{12}$-залежним ферментом метіонінсинтетазою, донором метильної групи для якої $€$ N-5-метилтетрагідрофолат, процес утворення якого відбувається в циклі активного фолату. Альтернативна реакція утворення метіоніну з ГЦ каталізується фролатнезалежним ферментом БГМТ, що присутній у печінці й нирках і донором метильних груп для якого є бетаїн. У реакціях метилування безпосереднім донором метильних груп $€$ не метіонін, а його похідне - S-аденозилметіонін, який утворюється при взаємодії метіоніну з АТФ під впливом фрерменту S-AMC. S-аденозилметіонін, втрачаючи метильну групу, перетворюється в S-аденозилгомоцистеїн, який під впливом фрерменту S-АГГ розщеплюється на аденозин і ГЦ.

Ми встановили, що експериментальний гіпертиреоз супроводжувався зростанням активності фрерментів циклу реметилування - БГМТ, S-AMC та S-АГГ (табл. 2). B обидва терміни дослідження під впливом L-тироксину активність БГМТ підвищувалася як у тканині печінки (на 38 та 45 \%), так і в нирках (на 35 та 47 \%). Активність S-AMC i S-AГГ достовірно зростала в печінці та нирках лише на 21-й день дослідження (відповідно, на 34 і 63 \% та 35 і $59 \%$ ).

На відміну від L-тироксину, застосування мерказолілу супроводжувалось пригніченням активності фрерментів циклу метилування в печінці й нирках (табл. 2). Зокрема, у тканині печінки активність БГМТ знизилась в обидва терміни дослідження, відповідно, на 35 і 45 \%, у тканині нирок - на 35 і 47 \%. Моделювання гіпотиреозу також викликало пригнічення фрункціональної активності S-AMC, яка в печінці на 14-й день дослідження зменшилась на $27 \%$, на 21-й - на 31 \%, а в нирках - на 33 і 40 \% відповідно. Що стосується S-АГГ, то тільки тривале введення мерказолілу (протягом 21-го дня) призводило до зниження (на $24 \%$ ) їі активності у тканині печінки, тоді як у нирках активність ферменту пригнічувалась і на 14-й, і на 21-й дні дослідження (відповідно, на 39 та 46 \%).

Активність $\mathrm{H}_{2} \mathrm{~S}$-синтезувальних ферментів ЦБС і ЦГЛ достовірно зростала при моделюванні гіпертиреозу, проте тільки в нирках і лише в разі тривалого (протягом 21-го дня) введення L-тироксину (табл. 3). Водночас при моделюванні гіпотиреозу десульсуразна активність ЦБС і ЦГЛ знижувалась на 21-й день дослідження (на $33 \%$ ), а активність ЦАТ - як на 14-й, так і на 21-й дні (відповідно, на 36 та 38 \%). У нирках під впливом мерказолілу достовірно зменшувалась

Таблиця 2 - Активність (нмоль/хв-мг білка) ферментів циклу метилування

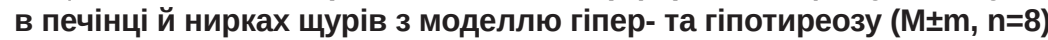

\begin{tabular}{|c|c|c|c|c|c|c|}
\hline \multirow{4}{*}{ Показник } & \multirow{4}{*}{$\begin{array}{c}\text { Об'єкт } \\
\text { дослідження }\end{array}$} & \multicolumn{5}{|c|}{ Група тварин } \\
\hline & & \multirow{3}{*}{ інтактні } & \multirow{2}{*}{\multicolumn{2}{|c|}{$\begin{array}{c}\text { модель гіпертиреозу } \\
\text { нас від початку введення } \\
\text { L-тироксину, дні }\end{array}$}} & \multicolumn{2}{|c|}{ модель гіпотиреозу } \\
\hline & & & & & $\begin{array}{r}\text { час від по } \\
\text { мерка }\end{array}$ & $\begin{array}{l}\text { в введення } \\
\text { лу, дні }\end{array}$ \\
\hline & & & 14 & 21 & 14 & 21 \\
\hline \multirow[t]{2}{*}{ S-AMC } & Печінка & $5,84 \pm 0,43$ & $6,08 \pm 0,59$ & $7,85 \pm 0,48^{*}$ & $4,25 \pm 0,29^{*}$ & $4,02 \pm 0,43^{\star}$ \\
\hline & Нирки & $3,04 \pm 0,27$ & $3,93 \pm 0,36$ & $4,96 \pm 0,28^{*}$ & $2,03 \pm 0,14^{*}$ & $1,82 \pm 0,26^{\star}$ \\
\hline \multirow[t]{2}{*}{ S-АГГ } & Печінка & $5,66 \pm 0,30$ & $5,91 \pm 0,48$ & $7,66 \pm 0,53^{*}$ & $4,80 \pm 0,42$ & $4,28 \pm 0,32^{\star}$ \\
\hline & Нирки & $3,83 \pm 0,36$ & $5,18 \pm 0,59$ & $6,08 \pm 0,50^{*}$ & $2,32 \pm 0,17^{*}$ & $2,08 \pm 0,18^{\star}$ \\
\hline \multirow[t]{2}{*}{ БГМТ } & Печінка & $8,65 \pm 0,50$ & $11,90 \pm 0,78^{*}$ & $12,50 \pm 0,89 *$ & $5,60 \pm 0,43^{*}$ & $4,95 \pm 0,27^{\star}$ \\
\hline & Нирки & $3,33 \pm 0,17$ & $4,48 \pm 0,21^{*}$ & $4,90 \pm 0,33^{*}$ & $2,15 \pm 0,19^{*}$ & $1,76 \pm 0,14^{\star}$ \\
\hline
\end{tabular}

Таблиця 3 - Активність (нмоль/хв· мг білка) ферментів синтезу $\mathrm{H}_{2} \mathrm{~S}$ у печінці й нирках щурів 3 моделлю гіпер- та гіпотиреозу $(\mathrm{M} \pm \mathrm{m}, \mathrm{n}=8)$

\begin{tabular}{|c|c|c|c|c|c|c|}
\hline \multirow{4}{*}{ Показник } & \multirow{4}{*}{$\begin{array}{c}\text { Об'єкт } \\
\text { дослідження }\end{array}$} & \multicolumn{5}{|c|}{ Група тварин } \\
\hline & & \multirow{3}{*}{ інтактні } & \multirow{2}{*}{\multicolumn{2}{|c|}{$\begin{array}{c}\text { модель гіпертиреозу } \\
\text { час від початку введення } \\
\text { L-тироксину, дні }\end{array}$}} & \multicolumn{2}{|c|}{ модель гіпотиреозу } \\
\hline & & & & & \multicolumn{2}{|c|}{$\begin{array}{c}\text { час від початку введення } \\
\text { мерказолілу, дні }\end{array}$} \\
\hline & & & 14 & 21 & 14 & 21 \\
\hline \multirow[t]{2}{*}{ ЦБС } & Печінка & $4,04 \pm 0,34$ & $4,38 \pm 0,45$ & $4,65 \pm 0,37$ & $3,28 \pm 0,22$ & $2,72 \pm 0,27^{*}$ \\
\hline & Нирки & $3,31 \pm 0,10$ & $3,33 \pm 0,22$ & $4,01 \pm 0,20^{*}$ & $2,70 \pm 0,18^{\star}$ & $2,37 \pm 0,25^{\star}$ \\
\hline \multirow[t]{2}{*}{ ЦГЛ } & Печінка & $4,01 \pm 0,20$ & $4,17 \pm 0,23$ & $4,30 \pm 0,16$ & $3,06 \pm 0,31$ & $2,70 \pm 0,21^{*}$ \\
\hline & Нирки & $0,92 \pm 0,04$ & $1,29 \pm 0,14$ & $1,84 \pm 0,15^{\star}$ & $0,58 \pm 0,03^{*}$ & $0,56 \pm 0,03^{*}$ \\
\hline \multirow[t]{2}{*}{ ЦАТ } & Печінка & $1,67 \pm 0,12$ & $1,41 \pm 0,20$ & $1,80 \pm 0,29$ & $1,07 \pm 0,14^{*}$ & $1,03 \pm 0,12^{*}$ \\
\hline & Нирки & $1,28 \pm 0,03$ & $1,44 \pm 0,08$ & $1,43 \pm 0,10$ & $1,20 \pm 0,10$ & $1,04 \pm 0,07^{*}$ \\
\hline
\end{tabular}


активність усіх фрерментів процесу транссульфування (ЦБС - на 18 і 28 \%, ЦГЛ - 37 та $39 \%$, відповідно, на 14-й і 21-й дні, ЦАТ - лише на 21-й день дослідження на 19 \%).

Таким чином, можемо констатувати, що при експериментальному гіпотиреозі пригнічуються шляхи десульфування цистеїну, що призводить до зменшення кількості утвореного в печінці й нирках гідроген сульфріду. Встановлено, що введення щурам протягом 14-ти днів мерказолілу зумовило зниження $\mathrm{H}_{2} \mathrm{~S}$ у крові на $17 \%$, а протягом 21-го дня - на 24 \% (рис. 1). Оскільки на сьогодні відомо, що $\mathrm{H}_{2} \mathrm{~S}$, як і $\mathrm{NO}$, має вазодилатаційні властивості й запобігає посиленому тромбоутворенню, то таке зменшення його вмісту при зниженій продукції тиреоїдних гормонів $є$ несприятливим. Можливо, цей фракт і пояснює виникнення ендотеліальної дисфрункції і кардіоваскулярних розладів, що виникають у хворих на гіпотиреоз.

Очевидно, сповільнення шляхів утилізації цистеїну за умов гіпотиреозу призвело до зростання його рівня в сироватці крові. Так, на 14-й день після введення мерказолілу вміст цистеїну підвищився на $24 \%$, а на $21-и ̆-$ на $39 \%$ (рис. 2).

Нагромадження цистеїну призведе до збільшення вмісту в крові ГЦ, який у нормі перетворюється до цистеїну у двох реакціях. Такому накопиченню сприятиме також пригнічення активності БГМТ, яке ми спостерігали в щурів 3 гіпотиреозом, внаслідок гальмування процесів реметилування ГЦ назаддо метіоніну. В нашому досліді на 14-й день при застосуванні мерказолілу вміст ГЦ збільшився на $98 \%$, а на 21-й - на $160 \%$ (рис. 3). Як і зниження рівня $\mathrm{H}_{2} \mathrm{~S}$, таке

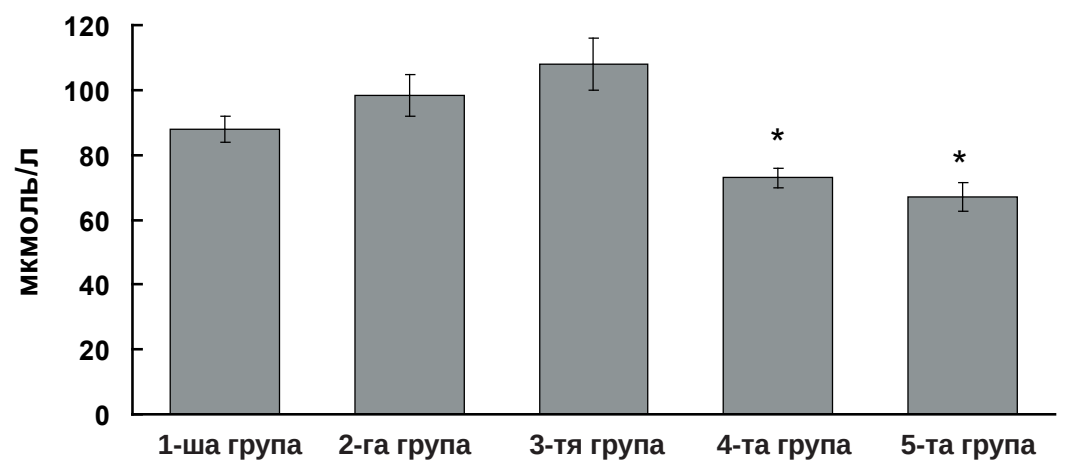

Рис. 1. Концентрація (мкмоль/л) $\mathrm{H}_{2} \mathrm{~S}$ у сироватці крові щурів з моделлю гіпер- та гіпотиреозу $(n=8)$. Примітка. Тут і на рисунках 2, 3: * - зміни достовірні відносно показників групи інтактних тварин.

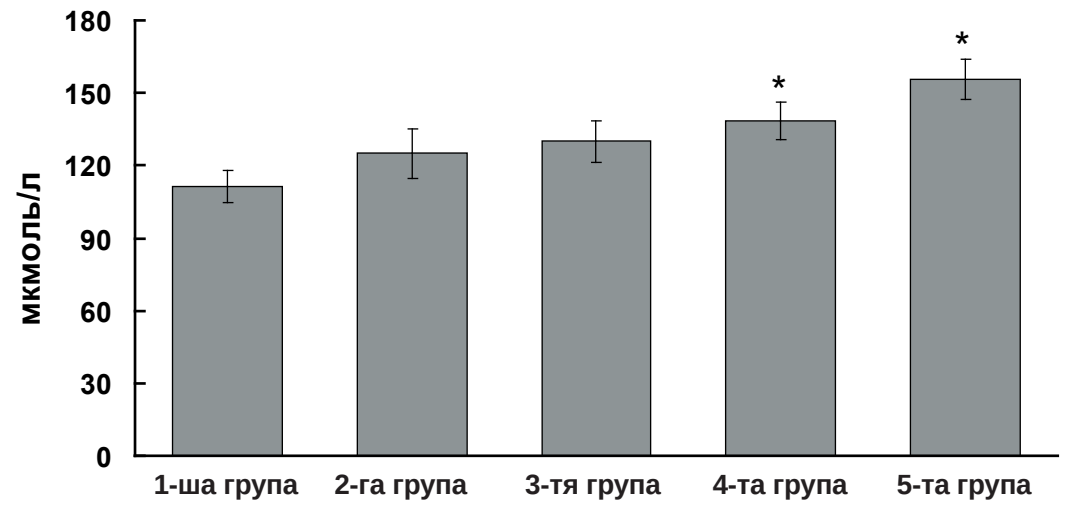

Рис. 2. Вміст (мкмоль/л) цистеїну в сироватці крові щурів з моделлю гіпер- та гіпотиреозу $(\mathrm{n}=8)$.

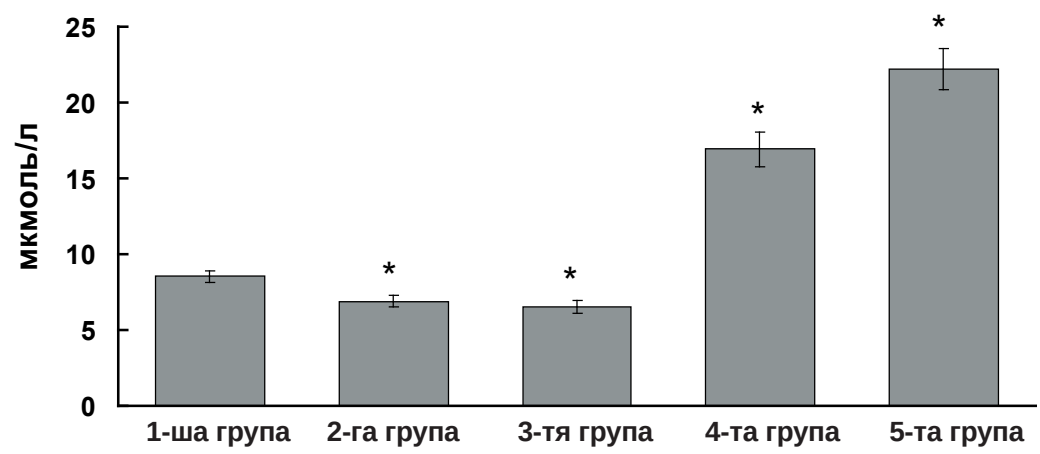

Рис. 3. Вміст (мкмоль/л) гомоцистеїну в сироватці крові щурів з моделлю гіпер- та гіпотиреозу $(\mathrm{n}=8)$. 
підвищення вмісту ГЦ у крові може бути важливим фрактором ризику розвитку кардіоваскулярної патології при гіпотиреоїдних станах.

ВИСНОВКИ. 1. Стан гіпертиреозу супроводжується підвищенням активності ферментів циклу реметилування в печінці й нирках та процесів транссульсрування в нирках і зниженням рівня ГЦ у крові.

2. Стан гіпотиреозу призводить до зниження активності фрерментів циклу реметилування i процесів транссульфрування в печінці й нирках, що супроводжується збільшенням рівня ГЦ і цистеїну та зменшенням концентрації гідроген сульфріду в крові.

3. Збільшення вмісту ГЦі цистеїну, зменшення рівня $\mathrm{H}_{2} \mathrm{~S}$ при гіпотиреозі можуть бути вагомими фракторами ризику розвитку атеросклерозу, ендотеліальної диссрункції та гіперкоагуляції при хворобах, що супроводжуються зниженням рівня тиреоїдних гормонів.

\section{СПИСОК ЛІТЕРАТУРИ}

1. Пат. України на корисну модель № 45018 U МПК (2009) G01N 33/00. Спосіб визначення продукції гідроген сульфіду в органах щурів / Заічко Н. В., Пентюк Н. О., Мельник А. В., Штатько О. І. ; заявник і патентовласник Науково-дослідний інститут реабілітації інвалідів (навчально-лікувальний комплекс) Вінницького національного медичного університету імені М. І. Пирогова. - № и 200904434 ; заявл. 05.05.09; опубл. 26.10.09, Бюл. № 20.

2. Пат. України на корисну модель № 52136 U МПК (2009) G01N 33/68. Спосіб визначення вмісту гідроген сульфріду в плазмі крові / Заічко Н. В., Пентюк Н. О., Мельник А. В. ; заявник і патентовласник НДІ реабілітації інвалідів н.н.л.к. Вінницького національного медичного університету імені М. І Пирогова. - № u 201003158; заявл. 19.03.10; опубл. 10.08.10, Бюл. № 15.

3. Brosnan J. T. The sulfur-containing amino acids: an overview / J. T. Brosnan, M. E. Brosnan // J. Nutr. 2006. - 136, № 6. - P. 1636-1640.

4. A novel hydrogen sulfide prodrug, SG1002, promotes hydrogen sulfide and nitric oxide bioavailability in heart failure patients / D. J. Polhemus, Z. Li, C. B. Pattillo [et. al] // Cardiovasc. Ther. -2015. - 33 (4). - P. 216-226.

5. Association between plasma homocysteine status and hypothyroidism: a meta-analysis / Y. Zhou, Y. Chen, X. Cao [et al.] // Int. J. Clin. Exp. Med. - 2014 - 15, № 7 (11). - P. 4544-4553.

6. Chiang P. K. Activation of methionin for transmethylation. Purification of the S-adenosylmethionine synthetase of bakers' yeast and its separation into two forms / P. K. Chiang, G. L. Cantoni // J. Biol. Chem. 1977. - 252, № 13. - P. 4506-4513.

\section{REFERENCES}

1. Zaichko, N.V., Pentiuk, N.O., Melnyk, A.V., Shtatko, O.I. (2009). Sposib vyznachennia produktsii hidrohen sulfidu $v$ orhanakh shchuriv [Method for determination of production of hydrogen-sulfide in animal organs] Patent UA, no. 45018 [in Ukrainian].

2. Zaichko, N.V., Melnyk, A.V., Pentiuk, N.O. (2010). Sposib vyznachennia vmistu hidrohen sulfidu plazmy
7. Dombkowski R. A. Hydrogen sulfide as an endogenous regulator of vascular smooth muscle tone in trout / R. A. Dombkowski, M. J. Russell, K. R. Olson // Am. J. Physiol. Regul. Integr. Comp. Physiol. - 2004. - 286, № 4. - P. 678-685.

8. Ericson L. E. Betaine-homocysteine methyltransferases. III. The methyl donor specificity of the transferase isolated from pig liver / L. E. Ericson // Acta. Chem. Scand. - 1960. - 14. - P. 2127-2134.

9. Gadalla M.M. Hydrogen sulfide as a gasotransmitter / M. M. Gadalla, S. H. Snyder // Neurochem. 2010. - 113. - P. 14-26.

10. Homocysteine, folate, and cobalamin levels in hyperthyroid women before and after treatment / A. Orzechowska-Pawilojc, M. Siekierska-Hellmann, A. Syrenicz [et al.] // Endokrynol. Pol. -2009. -60, № 6. - P. 443-448.

11. Isa Y. Effect of vitamin B6 deficiency on S-adenosylhomocysteine hydrolase activity as a target point for methionine metabolic regulation / Y. Isa, H. Tsuge, T. Hayakawa // J. Nutr. Sci. Vitaminol. - 2006. - 52, № 5. - P. 302-306.

12. Methimazole-induced hypothyroidism paradoxically decreases homocysteine / K. M. Colleran, L. A. Romero, D. A. Upton [et al.] // Metabolism. - 2005. - 54, № 4. - P. 460-465.

13. Stein A. Redox biology of hydrogen sulfide: Implications for physiology, pathophysiology, and pharmacology / A. Stein, Sh.M. Bailey // Redox. Biology. - 2013. 1. - P. 32-39.

14. Urinary sulphate excretion and progression of diabetic nephropathy in Type 1 diabetes / G. Andrésdóttir, S. J. Bakker, H. P. Hansen [et al.] // Diabet. Med. 2013. - 30, № 5. - P. 563-566.

krovi [Method for determination of content of hydrogensulfide in blood serum] Patent UA, no. 52136 [in Ukrainian].

3. Brosnan, J.T., Brosnan, M.E. (2006) The sulfurcontaining amino acids: an overview. Journal of Nutrition, 136 (6), 1636-1640.

4. Polhemus, D.J., Li, Z., Pattillo, C.B., Gojon, G.Sr., Gojon, G.Jr., Giordano. T. \& Krum, H. (2015). A novel 
hydrogen sulfide prodrug, SG1002, promotes hydrogen sulfide and nitric oxide bioavailability in heart failure patients. Cardiovascular Therapeutics, 33(4), 216-226. doi: 10.1111/1755-5922.12128.

5. Zhou, Y., Chen, Y., Cao, X., Liu, C., \& Xie, Y. (2014). Association between plasma homocysteine status and hypothyroidism: a meta-analysis. International Journal of Clinical and Experimental Medicine, 15, 7 (11), 4544-4553.

6. Chiang, P.K. \& Cantoni, G.L. (1977). Activation of methionin for transmethylation. Purification of the S-adenosylmethionine synthetase of bakers' yeast and its separation into two forms. The Journal of Biological Chemistry, 252 (13), 4506-4513.

7. Dombkowski, R.A., Russell, M.J., \& Olson, K.R. (2004). Hydrogen sulfide as an endogenous regulator of vascular smooth muscle tone in trout. American Journal of Physiology Regulatory, Integrative and Comparative Physiology, 286 (4), 678-685. doi:10.1152/ajpregu. 00419.2003.

8. Ericson, L.E. (1960). Betaine-homocysteine methyltransferases. III. The methyl donor specificity of the transferase isolated from pig liver. Acta. Chemica. Scandinavica, 14, 2127-2134.

9. Gadalla, M.M., \& Snyder, S.H. (2010). Hydrogen sulfide as a gasotransmitter. Journal of Neurochemistry, 113, 14-26. doi: 10.1111/j.1471-4159.2010.06580.x
10. Orzechowska-Pawilojc, A., Siekierska-HelImann, M., Syrenicz, A., Sworczak, K. (2009). Homocysteine, folate, and cobalamin levels in hyperthyroid women before and after treatment. Endokrynologia Polska, 60 (6), 443-448.

11. Isa, Y., Tsuge, H., \& Hayakawa, T. (2006). Effect of vitamin B6 deficiency on S-adenosylhomocysteine hydrolase activity as a target point for methionine metabolic regulation. Journal of Nutritional Science and Vitaminology, 52 (5), 302-306.

12. Colleran, K.M., Romero, L.A., Upton, D.A., \& Burge, M.R. (2005). Methimazole-induced hypothyroidism paradoxically decreases homocysteine. Metabolism: Clinical and Experimental, 54 (4), 460-465. doi: http:// dx.doi.org/10.1016/j.metabol.2004.10.013

13. Stein, A., \& Bailey, S.M. (2013) Redox biology of hydrogen sulfide: Implications for physiology, pathophysiology, and pharmacology. Redox. Biology, 1, 32-39. doi:10.1016/j.redox.2012.11.006

14. Andrésdóttir, G., Bakker, S.J., Hansen, H.P., Parving, H.H., Rossing, P. (2013). Urinary sulphate excretion and progression of diabetic nephropathy in Type 1 diabetes. Diabetic Medicine: a Journal of the British Diabetic Association, 30 (5), 563-566. doi: 10.1111/dme. 12131. Epub 2013 Mar 7.

\section{В. М. Нечипорук ${ }^{1}$ Н. В. Заичко ${ }^{1}$ М. М. Корда ${ }^{2}$ ВИННИЦКИЙ НАЦИОНАЛЬНЫЙ МЕДИЦИНСКИЙ УНИВЕРСИТЕТ ИМЕНИ Н. И. ПИРОГОВА ${ }^{1}$ ТЕРНОПОЛЬСКИЙ ГОСУДАРСТВЕННЫЙ МЕДИЦИНСКИЙ УНИВЕРСИТЕТ ИМЕНИ И. Я. ГОРБАЧЕВСКОГО \\ ВЛИЯНИЕ ТИРЕОИДНЫХ ГОРМОНОВ НА ПРОЦЕССЫ РЕМЕТИЛИРОВАНИЯ И ТРАНССУЛЬФУРИРОВАНИЯ СЕРОСОДЕРЖАЩИХ АМИНОКИСЛОТ В ОРГАНАХ КРЫС}

\section{Резюме}

Вступление. Серосодержащие аминокислоты обеспечивают процессы жизнедеятельности клетки и процессы метилирования, поддерживают редокс-потенциал и целостность клеточных систем, обезвреживают токсичные агенты и свободные радикалы. Нарушения их обмена ассоциируются с рядом патологий, включая болезнь Альцгеймера, развитием злокачественных опухолей, дефектами невральной трубки, болезнями почек. Повышение в крови концентрации серосодержащей аминокислоты гомоцистеина (ГЦ) является серьезным фрактором развития заболеваний сердечно-сосудистой системы: атеросклероза, гипертонии, венозного тромбоза. Регуляция метаболизма серосодержащих аминокислот осуществляется на разных уровнях, в том числе и тиреоидными гормонами. Установлено, что гипотиреоз является независимым фактором, который приводит к увеличению концентрации ГЦ в крови и риска развития сердечно-сосудистых заболеваний. Однако конкретные молекулярные механизмы влияния тиреоидных гормонов на обмен серосодержащих аминокислот остаются неизвестными.

Цель исследования - изучить в эксперименте влияние тиреоидных гормонов на процессы реметилирования и транссульфурирования в печени и почках, содержание ГЦ, цистеина и гидроген сульфрида в сыворотке крови экспериментальных животных.

Методы исследования. Крысам вводили L-тироксин и мерказолил для моделирования состояний гипер- и гипотиреоза, которые подтверждали по содержанию свободного тироксина, свободного трийодтиронина и тиреотропного гормона в сыворотке крови.

Результаты о обсуждение. В печени и почках животных с гипотиреозом наблюдали снижение активности фрерментов цикла реметилирования - S-аденозилметионинсинтетазы, S-аденозилгомо- 
цистеингидролазы, бетаингомоцистеинметилтрансферазы и фрерментов транссульфурирования - цистатионин- $\beta$-синтазы, цистатионин-у-лиазы и цистеинаминотрансореразы. При моделировании гипертиреоза активность данных ферментов в исследуемых органах повышалась. Гипертиреоз сопровождался снижением концентрации ГЦ, а гипотиреоз - возрастанием концентрации ГЦ, цистеина и уменьшением содержания гидроген сульфида в крови животных.

Вывод. Весомыми фракторами риска развития атеросклероза, эндотелиальной диссрункции и гиперкоагуляции при гипотиреоидных состояниях могут быть нарушения процессов реметилирования и транссульфурирования серосодержащих аминокислот в органах.

КЛЮЧЕВЫЕ СЛОВА: тиреоидные гормоны; серосодержащие аминокислоты; цикл реметилирования; путь транссульфурирования; гомоцистеин; цистеин; гидроген сульфид.

V. M. Nechyporuk' ${ }^{1}$ N. V. Zaichko' ${ }^{1}$ M. M. Korda M. PYROHOV VINNYTSIA NATIONAL MEDICAL UNIVERSITY, VINNYTSIA ${ }^{1}$ I. HORBACHEVSKY TERNOPIL STATE MEDICAL UNIVERSITY²

\section{EFFECT OF THYROID HORMONES ON THE SULFUR-CONTAINING AMINO ACIDS REMETHYLATION AND TRANSSULFURATION PATHWAYS IN RATS’ ORGANS}

\section{Summary}

Introduction. Sulfur-containing amino acids affect the vital processes of cells and methylation processes support the redox potential and integrity of cellular systems, incapacitate toxicants and free radicals. Disorder of sulfurcontaining amino acids metabolism is associated with different pathologies, including Alzheimer's disease, malignant tumors, neural tube defects, kidneys diseases. The increase of sulfur-containing amino acid homocysteine in the blood is a serious risk factor of cardiovascular diseases such as atherosclerosis, hypertension, venous thrombosis. Regulation of sulfur-containing amino acids metabolism is carried out at different levels, including thyroid hormones. It was shown that hypothyroidism is an independent factor leading to an increase in the concentration of homocysteine in the blood and the risk of cardiovascular diseases development. However, specific molecular mechanisms of the effect of thyroid hormones on sulfur-containing amino acids metabolism are still unknown.

The aim of the study - to investigate experimentally the effect of thyroid hormones on remethylation and transsulfuration pathways in the liver and kidneys, homocysteine, cysteine and hidrogen sulfide contents in the blood serum of experimental animals.

Methods of the research. L-thyroxine and Mercazolil were used for the modeling of hyper-and hypothyroidism, which were confirmed by the content of free thyroxine, free triiod othyronine, thyroid-stimulating hormone in serum.

Results and Discussion. A decrease in the activity of remethylation cycle enzymes (S-adenosylmethionine synthetase, S-adenosylhomocysteine hydrolase and betaine-homocysteine methyltransferase), as well as transsulfuration pathway enzymes (cystathionine $\beta$-synthase, cystathionine $y$-lyase, cysteine transaminase) in the liver and kidneys of animals with hypothyroidism was observed. At the same time, introduction of L-thyroxine increased the activity of these enzymes in the liver and kidney tissues. Hyperthyroidism caused the decrease of homocysteine concentration whereas hypothyroidism increased the levels of homocysteine, cysteine and decreased the hydrogen sulpide content in blood.

Conclusions. Disorders of remethylation and transsulfuration of sulfur-containing amino acids in organs might be important risk factors of atherosclerosis, endothelial dysfunction, and hypercoagulation development.

KEY WORDS: thyroid hormones; sulfur-containing amino acids; remethylation cycle; transsulfuration pathway; homocysteine; cysteine; hydrogen sulfide.

Адреса для листування: В. М. Нечипорук, Вінницький національний медичний університет імені М. І. Пирогова, вул. Пирогова, 56 Вінниця, 21018, Україна. 